\title{
EVALUASI DAYA TAMPUNG TERHADAP BEBAN PENCEMAR MENGGUNAKAN MODEL KUALITAS AIR (STUDI KASUS: SUNGAI WINONGO)
}

\author{
Nelly Marlina', Kasam², dan Any Juliani ${ }^{3}$ \\ 1,2,3Pusat Studi Teknik Lingkungan Universitas Islam Indonesia \\ Email: nelly_marlina02@yahoo.com
}

\begin{abstract}
The increasing of human's activities caused the pollution load going up. It affected the amount of the Winongo River's capacity. One of the river management attempts was find out the amount of the capacity with a modeling method. The modeling program in this research was Qual2Kw. The research method was supported by the secondary and primary data treated by the Qual2Kw program. This research was divided in three scenarios. The trial results showed that the BOD concentration in the along of the river was $16 \mathrm{mg} / \mathrm{L}$, the DO concentration was $2.4 \mathrm{mg} / \mathrm{L}, 7 \mathrm{of} \mathrm{pH}$, and $26 \circ \mathrm{C}$ of temperature. The condition of BOD from the upstream to the downstream in the existing condition had exceeded the quality standards, $3 \mathrm{mg} / \mathrm{L}$. The attempts to decrease the pollution load capacity of Winongo River by 2012 was decreasing the pollution load from the point source $959.25 \mathrm{~kg} /$ day and from the diffuser source was $193.75 \mathrm{~kg} /$ day. The another effort was making the IPAL Komunal in each sub-districts.
\end{abstract}

Keywords: Winongo River, capacity, Qual2Kw

\section{PENDAHULUAN}

Peningkatan aktifitas penduduk dapat mempengaruhi kualitas sungai baik secara langsung maupun tidak langsung. Salah satu wujud dari perubahan kondisi sungai adalah terjadinya degradasi kualitas air sungai. Hal tersebut disebabkan oleh berlebihnya daya tampung beban pencemaran baik dari aktifitas domestic maupun non-domestik. Oleh sebab itu, salah satu upaya dalam pengelolaan sungai adalah mencari besaran daya tampung yang diterima oleh sungai dengan metode pemodelan. Salah satu program pemodelan yang banyak digunakan adalah Qual2Kw yang dikembangkan oleh United States Environmental Potecion Agency.

Penelitian kali ini dilakukan untuk mengetahui daya tampung Sungai Winongo yang merupakan anak sungai Opak dengan panjang sungai utama kurang lebih $53,83 \mathrm{~km}$. Hulu Sungai Winongo berlokasikan di
Kec.Turi,Kec.Sleman, Kec Mlati dan Kec.Gamping,

Kabupaten Sleman dan bermuara di Sungai Opak, Kab.Bantul. Sedangkan Daerah Aliran Sungai (DAS) Winongo memiliki luasan $118 \mathrm{Km} 2$ yang dimanfaatkan oleh penduduk untuk berbagai aktifatas antropogenik, meliputi aktifitas pertanian, Rumah Sakit, Peternakan, Perdagangan, Industri, Pemukiman, Bengkel, Rumah Makan, dsb.

Tujuan penelitiannya adalah:

1. Mengetahui tingkat pencemaran organik berupa BOD (Biochemical Oxygen Demand)

2. Menghitung daya tampung/kemampuan badan air sungai Winongo dalam menerima beban pencemar dengan software Qual2Kw

3. Memberikan saran alternatif pengelolaan dalam usaha pengendalian kualitas air sungai Winongo. 


\section{METODE}

1. Diagram Alir Penelitian

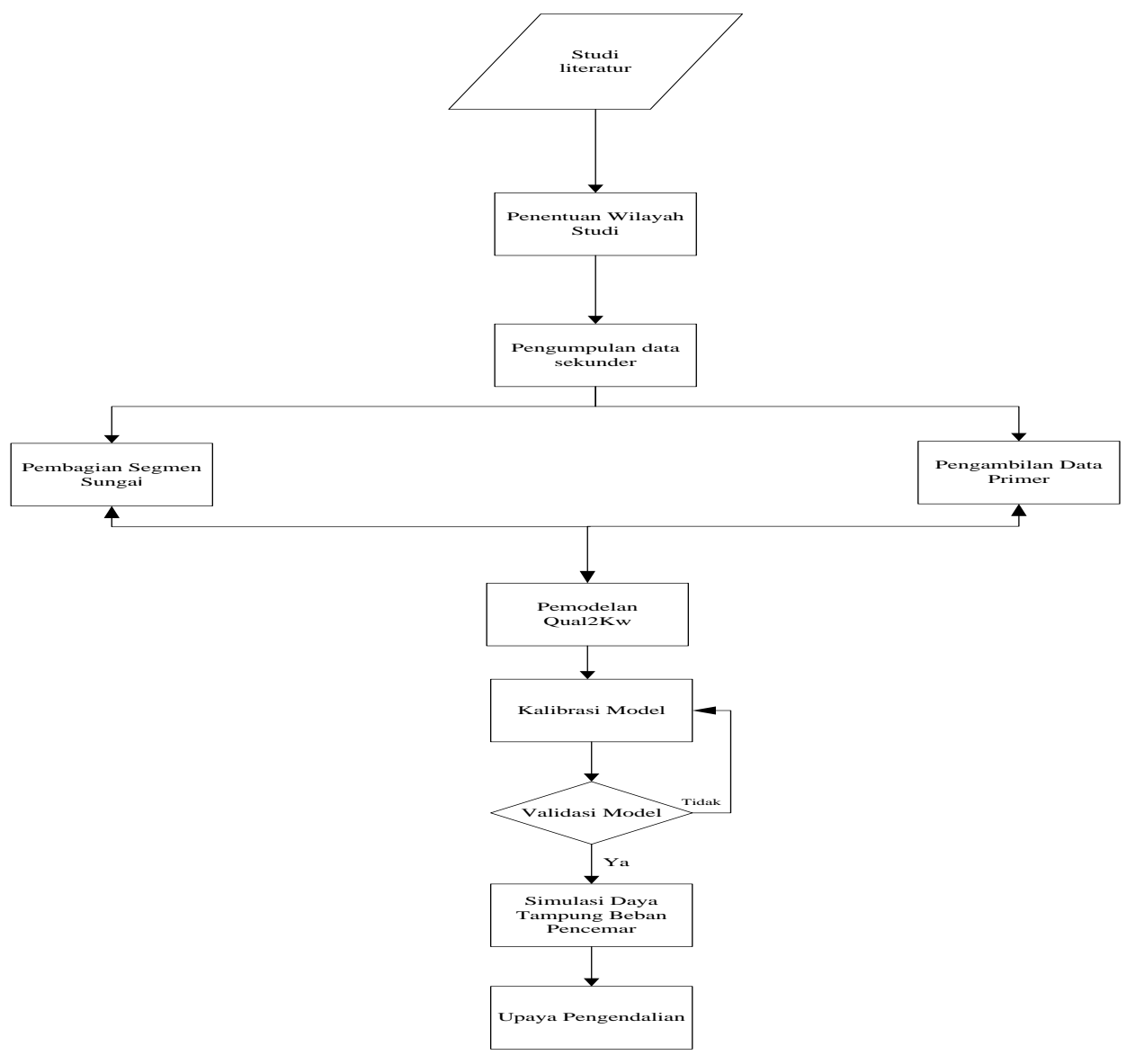

Gambar 1. Diagram Alir Penelitian

2. Studi Literatur

Data sekunder mencakup data monitoring kualitas air sepanjang Sungai Winongo, Lokasi sumber pencemar pada sungai, Peta dasar sungai Winongo, Peraturan Kriteria Mutu Sumber Air. Sedangkan data Primer meliputi data kualitas air yang diambil pada bulan Juli 2012.

3. Kalibrasi dan Validasi Model

Kalibrasi adalah proses penentuan harga koefisien yang paling sesuai, sehingga perbandingan hasil modeldengan data lapangan menunjukan harga yang paling baik ditinjau secara statistic (Schnoor,1997 dalam Marlina 2011).

Validasi model dilakukan dengan metode Root Mean Square Percent Error (RMSPE) yang digunakan untuk mengkuantifikasi besar dan sifat error yang terjadi. RMSPE mengukur rata-rata prosentase perbedaan antara data aktual dan hasil simulasi, dengan menggunakan rumus.

$$
\text { RMSPE }=\sqrt{\frac{1}{n}\left[\sum_{n=1}^{n}\left(\frac{S t-A t}{A t}\right)^{2}\right]} \times 100 \%
$$

Keterangan:

RMSPE: Root Mean Square Percent Error St : Nilai simulasi pada waktu $t$

At : Nilai aktual pada waktu $t$

$\mathrm{n}$ : Jumlah pengamatan $(\mathrm{t}=1,2, \ldots \ldots, \mathrm{n})$

4. Simulasi Daya Tampung Dengan Berbagai Skenario

Model yang telah terkalibrasi dengan baik dimodifikasi untuk melihat pengaruh parameter-parameter dalam menghasilkan output yang diinginkan. Beberapa skenario 
yang digunakan dalam model Qual2Kw dapat dilihat dalam tabel berikut;

HASIL DAN PEMBAHASAN

1. Pembagian Segmen dan Kualitas Sungai Winongo

Tabel 2. Segmen Sungai Winongo

\begin{tabular}{|c|c|c|c|c|c|c|}
\hline \multirow{2}{*}{ Kode } & \multirow{2}{*}{$\begin{array}{c}\text { Nama } \\
\text { Segmen }\end{array}$} & \multirow{2}{*}{$\begin{array}{l}\text { Panjang } \\
(\mathrm{Km})\end{array}$} & \multicolumn{2}{|c|}{ Elevasi (m) } & \multicolumn{2}{|c|}{ Koordinat } \\
\hline & & & Hulu & Hilir & Hulu & Hilir \\
\hline TS 1 - TS 2 & $\begin{array}{l}\text { Karanggawang } \\
\text { - Denggung }\end{array}$ & 4,14 & 917 & 435 & $\begin{array}{c}7^{\circ} 38^{\prime} 6^{\prime \prime} \text { LS } \\
110^{\circ} 22^{\prime} 60^{\prime \prime} \\
\text { BT }\end{array}$ & $\begin{array}{c}7^{\circ} 40^{\prime} 40^{\prime \prime} \mathrm{LS} \\
110^{\circ} 22^{\prime} 35^{\prime \prime} \mathrm{BT}\end{array}$ \\
\hline TS 2 - TS 3 & $\begin{array}{l}\text { Denggung - } \\
\text { Jatimulyo }\end{array}$ & 11,70 & 435 & 147 & $\begin{array}{c}7^{\circ} 40^{\prime} 40^{\prime \prime} \text { LS } \\
110^{\circ} 225^{\prime \prime} \\
\text { BT }\end{array}$ & $\begin{array}{c}7^{\circ} 46^{\prime} 37^{\prime \prime} \text { LS } \\
110^{\circ} 21^{\prime} 27^{\prime \prime} \text { BT }\end{array}$ \\
\hline TS 3 - TS 4 & $\begin{array}{l}\text { Jatimulyo - } \\
\text { Jlagran }\end{array}$ & 1,81 & 147 & 119 & $\begin{array}{c}7^{\circ} 46^{\prime} 37^{\prime \prime} \mathrm{LS} \\
110^{\circ} 21^{\prime} 27^{\prime \prime} \\
\text { BT }\end{array}$ & $\begin{array}{c}7^{\circ} 46^{\prime} 36^{\prime \prime} \text { LS } \\
110^{\circ} 21^{\prime} 21^{\prime \prime} \text { BT }\end{array}$ \\
\hline TS 4 - TS 5 & $\begin{array}{l}\text { Jlaglaran - } \\
\text { Tamansari }\end{array}$ & 2,47 & 119 & 117 & $\begin{array}{c}7^{\circ} 46^{\prime} 36^{\prime \prime} \mathrm{LS} \\
110^{\circ} 21^{\prime} 21^{\prime \prime} \\
\text { BT }\end{array}$ & $\begin{array}{c}7^{\circ} 47^{\prime} 23^{\prime \prime} \text { LS } \\
110^{\circ} 21^{\prime} 24^{\prime \prime} \text { BT }\end{array}$ \\
\hline TS 5 - TS 6 & $\begin{array}{l}\text { Tamansari - } \\
\text { Dongkelan }\end{array}$ & 2,49 & 117 & 98 & $\begin{array}{c}7^{\circ} 47^{\prime} 23^{\prime \prime} \mathrm{LS} \\
110^{\circ} 21^{\prime} 24^{\prime \prime} \\
\text { BT }\end{array}$ & $\begin{array}{c}7^{\circ} 49^{\prime} 40^{\prime \prime} \text { LS } \\
110^{\circ} 21^{\prime} 6 \text { " BT }\end{array}$ \\
\hline TS 6 - TS 7 & $\begin{array}{l}\text { Dongkelan - } \\
\text { Bakulan }\end{array}$ & 9,81 & 98 & 33 & $\begin{array}{c}7^{\circ} 49^{\prime} 40^{\prime \prime} \mathrm{LS} \\
110^{\circ} 21^{\prime} 6^{\prime \prime} \\
\text { BT }\end{array}$ & $\begin{array}{c}7^{\circ} 54^{\prime} 32 \text { " LS } \\
110^{\circ} 20^{\prime} 53^{\prime \prime} \text { BT }\end{array}$ \\
\hline TS 7 - TS 8 & Bakulan - Mojo & 8,86 & 33 & 30 & $\begin{array}{c}7^{\circ} 54^{\prime} 32 " \mathrm{LS} \\
110^{\circ} 20^{\prime} 53^{\prime \prime} \\
\text { BT }\end{array}$ & $\begin{array}{c}7^{\circ} 54^{\prime} 32 \text { " LS } \\
110^{\circ} 20^{\prime} 53^{\prime \prime} \text { BT }\end{array}$ \\
\hline
\end{tabular}

Tabel 3. Kualitas Sungai Winongo

\begin{tabular}{|c|c|c|c|c|c|c|c|c|r|r|}
\hline & & \multicolumn{7}{|c|}{ Hasil uji } & \multirow{2}{*}{ Rata } \\
\cline { 3 - 13 } Parameter & Satuan & $\begin{array}{c}\text { TS. } \\
1\end{array}$ & $\begin{array}{c}\text { TS. } \\
2\end{array}$ & TS. 3 & TS. 4 & TS. 5 & TS. 6 & TS. 7 & TS. 8 & \\
\hline DHL & $\begin{array}{c}\mu \mathrm{mhos} / \\
\mathrm{cm}\end{array}$ & 195 & 193 & 307 & 318 & 343 & 347 & 406 & 466 & 322 \\
\hline $\mathrm{suhu}$ & ${ }^{\circ} \mathrm{C}$ & 23 & 25 & 25 & 27 & 25 & 29 & 27 & 25 & 26 \\
\hline $\mathrm{pH}$ & & 7.09 & 6.49 & 6.48 & 6.74 & 6.73 & 6.9 & 6.88 & 7.1 & 7 \\
\hline $\mathrm{BOD}$ & $\mathrm{mg} / \mathrm{l}$ & 9.39 & 7.5 & 24.24 & 17.9 & 14.7 & 15.89 & 22.65 & 14.3 & 16 \\
\hline $\mathrm{DO}$ & $\mathrm{mg} / \mathrm{l}$ & 2.41 & 2.37 & 2.56 & 2.51 & 2.23 & 2.43 & 2.46 & 2.36 & 2.4 \\
\hline
\end{tabular}

Sumber: data sampling 2012 
2. Haril Trial Kalibrasi dan Validasi Model

Tabel 4. Koefisien laju reaerasi dan koefisien Laju Oksidasi Hasil Kalibrasi

\begin{tabular}{|c|c|c|c|}
\hline $\begin{array}{c}\text { Reach } \\
\text { number }\end{array}$ & $\begin{array}{c}\text { Reach } \\
\text { label }\end{array}$ & $\begin{array}{c}\text { Prescribed } \\
\text { Reaeration }\end{array}$ & $\begin{array}{c}\text { Fast } \\
\text { CBOD } \\
\text { Oxidation } \\
\text { Rate }\end{array}$ \\
\hline & & $/ d$ & /d \\
\hline 1 & TS 1 & 0,250 & 0,2 \\
\hline 2 & TS 2 & 0,250 & 0,2 \\
\hline 3 & TS 3 & 0,250 & 0,2 \\
\hline 4 & TS 4 & 0,100 & 0,2 \\
\hline 5 & TS 5 & 0,100 & 0,2 \\
\hline 6 & TS 6 & 0,250 & 0,2 \\
\hline 7 & TS 7 & 0,450 & 0,2 \\
\hline
\end{tabular}

Perbandingan BOD lap dan BOD Model

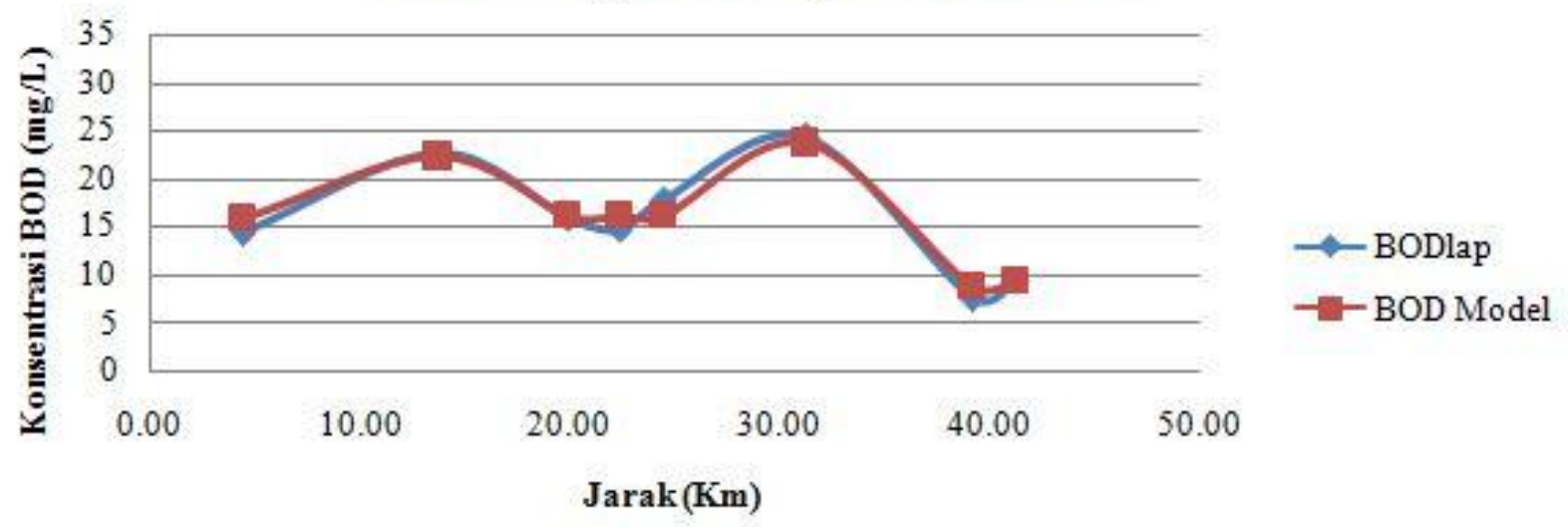

Gambar 2. Perbandingan BOD Lapangan dengan BOD Model

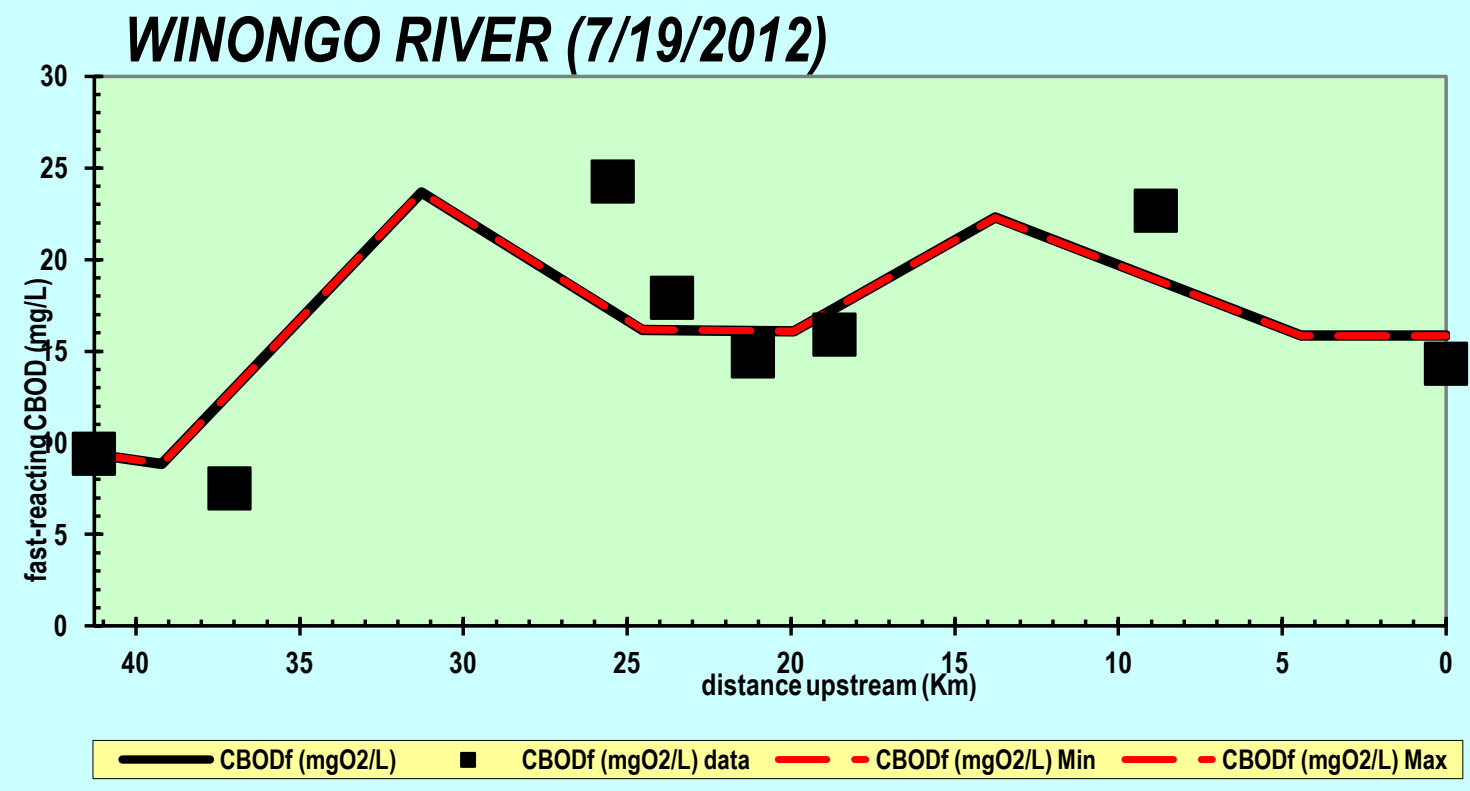

Gambar 3. Perbandingan BOD Lapangan dengan BOD Model Hasil Validasi Model output Qual2Kw 
Berdasarkan hasil perhitungan validasi dengan menggunakan rumus Root Mean Square Percent Error, diperoleh uji validitas data model dengan data lapangan adalah

\section{Pengembangan Model}

Hasil Stimulasi Skenario 1 sebesar 0,4\%. Hal ini menunjukkan bahwa, model bisa digunakan untuk simulasi skenario.

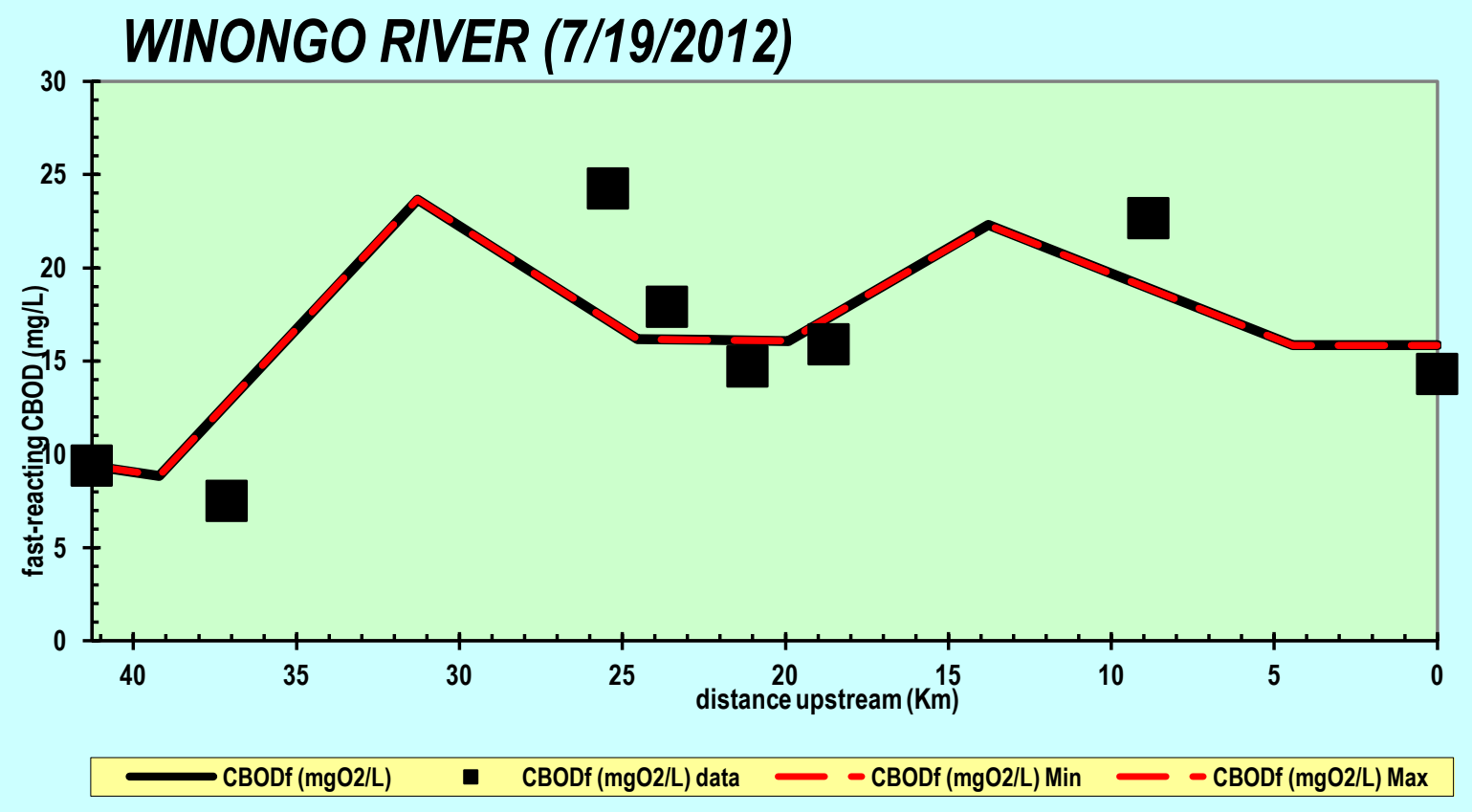

Gambar 4. Grafik Kondisi Existing kualitas Air parameter BOD Sungai Winongo

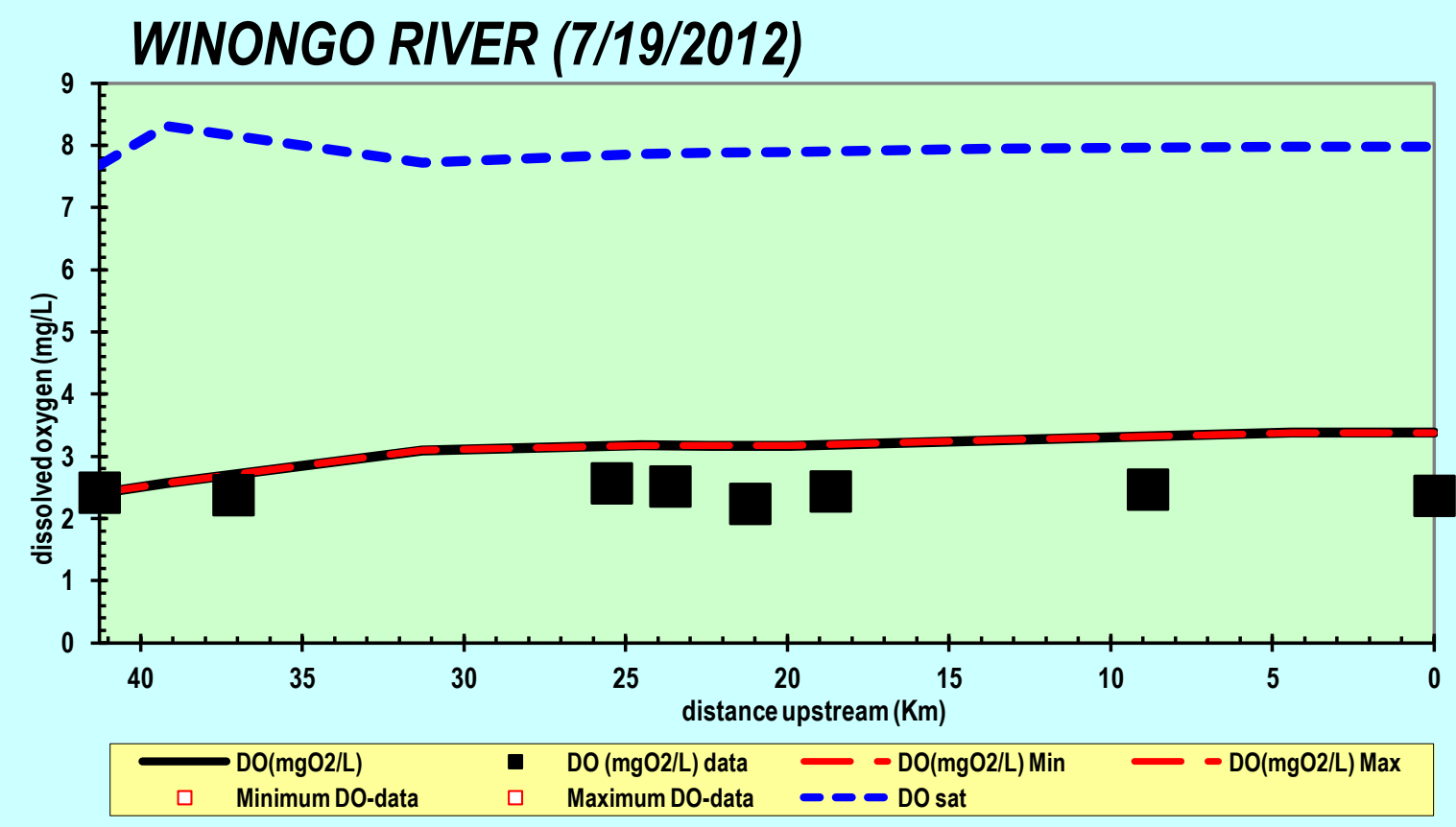

Gambar 5. Grafik Kondisi Existing kualitas Air parameter DO Sungai Winongo 
Hasil Stimulasi Skenario 2

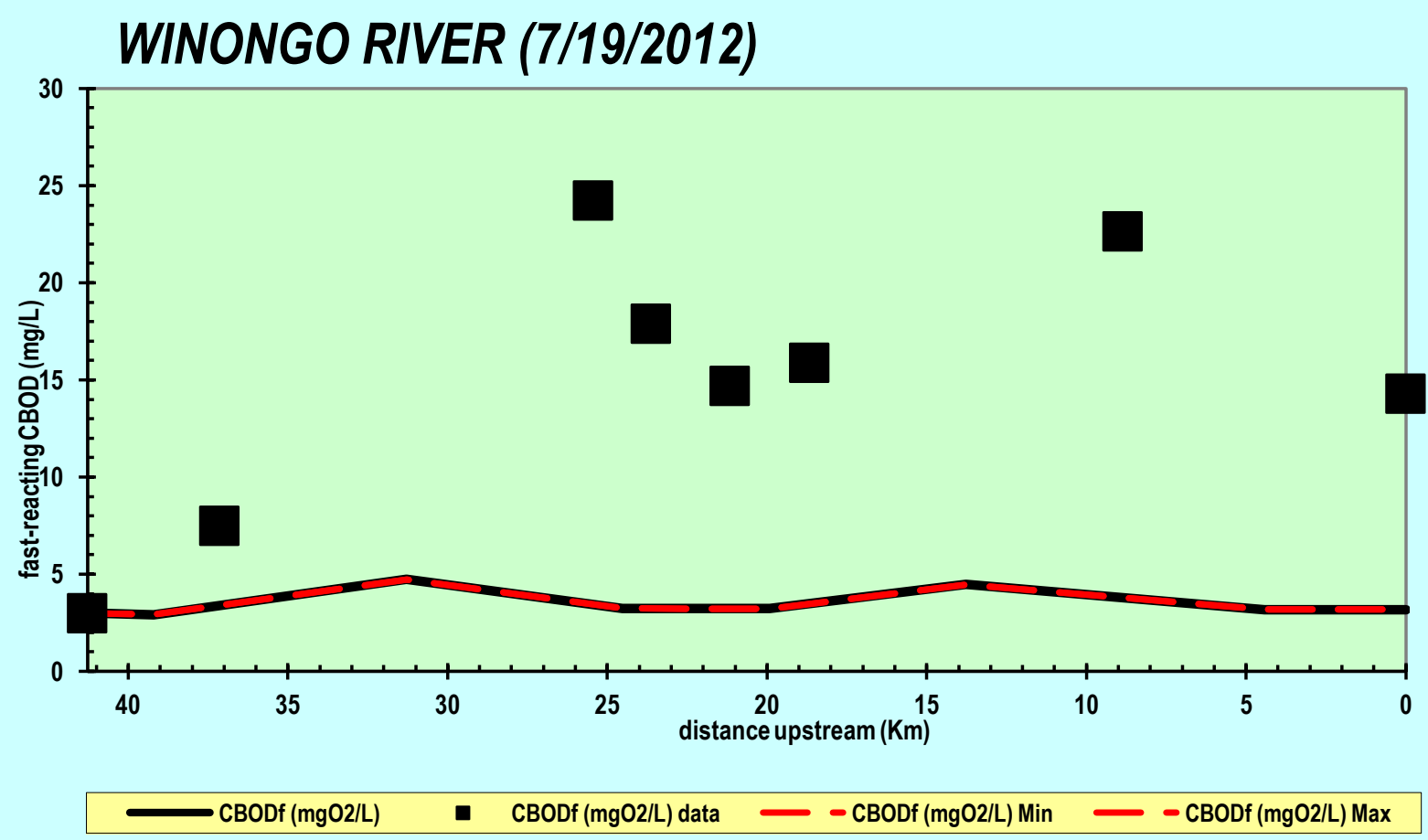

Gambar 6. Grafik Kondisi Existing kualitas Air parameter BOD Sungai Winongo

Hasil Stimulasi Skenario 3

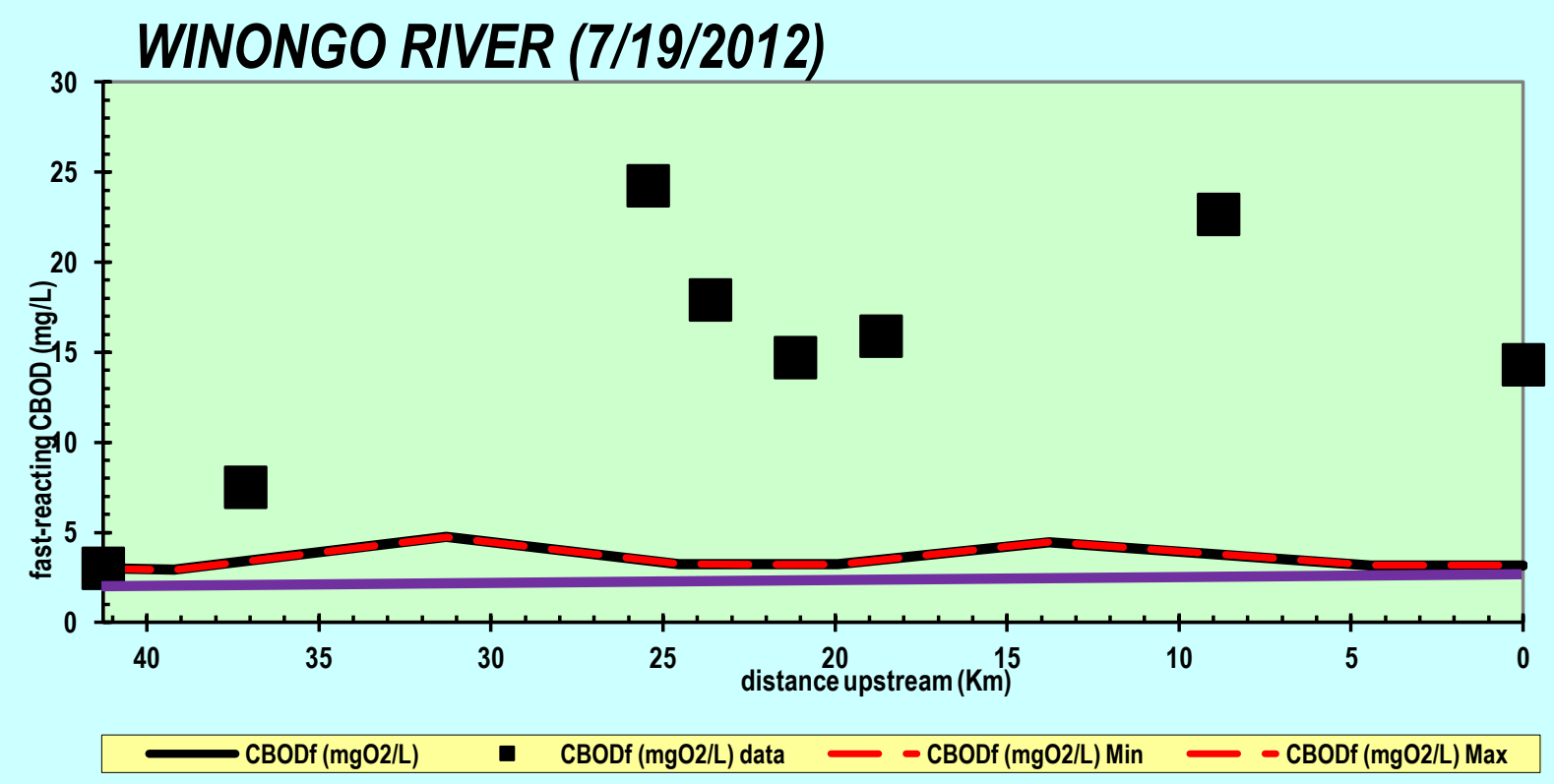

Gambar 7. Grafik Kondisi Existing kualitas Air parameter BOD Sungai Winongo

Keterangan: = baku mutu BOD $3 \mathrm{mg} / \mathrm{l}$ 
Stimulasi Skenario I menunjukkan konsentrasi BOD dan DO dari hulu ke hilir yang mengalami kenaikan dan penurunan. kondisi existing dan hasil permodelan profil BOD dan DO dari hulu hingga hilir dengan Program Qual2Kw. Berdasarkan hasil grafik Skenario I, menunjukan bahwa BOD model (Garis merah ) dan BOD hasil pemantauan (kotak-kotak) memiliki pola grafik yang sama, yakni konsentrasi BOD semakin ke hilir (kilometer 0) terjadi penurunan. Dari hasil grafik dapat dilihat bahwa peningkatan BOD terjadi pada $\mathrm{Km} 25$ yaitu sebesar 24,24 mg/L, hal ini terjadi karena $\mathrm{Km} 25$ sudah memasuki daerah kota yang merupakan pemukiman padat dan banyak terdapat kegiatan industri disekitarnya. Penurunan konsentrasi BOD terjadi pada $\mathrm{Km} 24$ sampai $\mathrm{Km} 18$ yaitu sebesar $14,04 \mathrm{mg} / \mathrm{L}$. Terjadinya penurunan konsentrasi ini dipengaruhi oleh adanya penambahan oksigen dari atmosfer dan dari anak sungai yang masuk pada segmen tersebut. Sedangkan konsentrasi DO atau oksigen terlarut yang terukur rata-rata 2,4 $\mathrm{mg} / \mathrm{L}$. Rendahnya konsentrasi DO dimungkinkan karena limbah domestik, industri yang masuk ke sungai winongo besar. Kandungan oksigen didalam air akan menerima tambahan akibat turbulensi sehingga berlangsung perpindahan oksigen dari udara ke air dan proses ini adalah proses reaerasi. Menurut Novonty and Olem, 1994, dalam Effendi, 2003.Mengacu pada data lapangan, kecepatan aliran air pada Km 24-18 cukup besar yaitu antara 1,4-0,8 m/s, sehingga air yang bergerak cepat memperkenankan molekul oksigen menembus permukaan, menghasilkan transfer gas dari udara kedalam air akan terlepas bersama-sama ke udara melalui permukaan. Gerakan kedua arah tersebut mengikuti kecepatan masing-masing yang ditentukan oleh temperatur dan variabelvariabel lain. Hasil dapat dilihat dalam Gambar 3 dan 4

Merujuk pada Baku Mutu Air Kelas II, menunjukan untuk parameter BOD. konsentrasi BOD dari hulu ke hilir telah melebihi ambang batas kriteria mutu air Kelas II yaitu di atas $3 \mathrm{mg} / \mathrm{L}$. Hal tersebut dapat dilihat pada Gambar 8

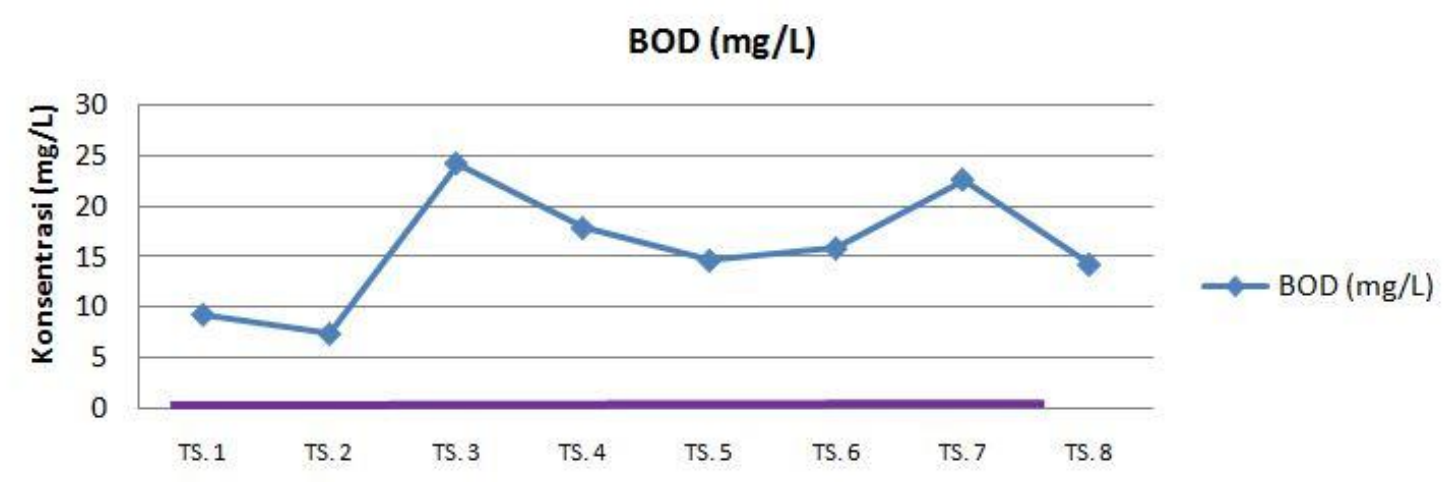

Gambar 8. Konsentrasi BOD dibandingkan dengan konsentrasi baku mutu air yang diizinkan

Keterangan:

TS.1 = Titik Sampling 1

- Batas Baku Mutu Air yang diizinkan untuk BOD = $3 \mathrm{mg} / \mathrm{L}$

Berdasarkan data sebenarnya dari masingmasing point source dan data estimasi konsentrasi BOD non-point source berdasarkan hasil perhitungan, Tabel 2 dan 3 menunjukkan total beban pencemaran untuk parameter BOD di Sungai Winongo adalah sebesar 28,7 ton/jam untuk point source dan 11,81 ton/jam untuk diffuse source.

Skenario II, Skenario ke dua dilakukan dengan cara mengurangi beban pencemar yang berasal dari point source. Alhasil, terjadi penurunan konsentrasi BOD dari hulu ke hilir. 
Hasil scenario II dapat dilihat dalam Gambar 6.

Pada skenario III, dilakukan simulasi dengan mengasumsikan beban pencemar berupa konsentrasi BOD yang berasal dari point source dan diffuse source lebih ketat 20\% dari Baku Mutu Air Limbah(BMAL) Nasional. Sedangkan untuk limbah rumah tangga diasumsikan telah diolah sehingga mutunya $20 \%$ lebih ketat dibandingkan baku mutu limbah nasional. Sehingga hasil simulasi skenario ketiga memperlihatkan bahwa upaya terpadu penurunan beban pencemar baik dihulu maupun sepanjang sungai winongo, berhasil memenuhi Baku Mutu Air untuk kelas II. Penurunan beban pencemar dilakukan dengan mengetatkan BMAL 20\% untuk industri dan domestik yang membuang limbahnya sungai Winongo sehingga kualitas air sungai Winongo bisa memenuhi baku mutu air kelas II.

Untuk mengetahui besarnya DTBP Sungai Winongo (Skenario 3), maka dihitung daya tampung beban pencemaran berdasarkan baku mutu Kelas II dan diperoleh hasil sebagai berikut. Model Qual2Kw BOD disesuaikan dengan metode trial dan error sampai mendekati pada nilai ambang batas baku mutu Kelas II yaitu $3 \mathrm{mg} / \mathrm{L}$ untuk parameter BOD.

Tabel 5. Perhitungan Daya Tampung Beban Pencemar Parameter BOD

\begin{tabular}{|c|c|c|c|}
\hline Segmen & $\begin{array}{c}\text { Beban BOD Maksimum } \\
\text { (Kg/hari) }\end{array}$ & $\begin{array}{c}\text { Beban BOD Sebenarnya } \\
\text { (kg/hari) }\end{array}$ & $\begin{array}{c}\text { Daya Tampung } \\
\text { (kg/hari) }\end{array}$ \\
\hline 1 & 1.452 & 3.240 & -1.788 \\
\hline 2 & 4.405 & 10.856 & -6.451 \\
\hline 3 & 30.550 & 233.373 & -202.823 \\
\hline 4 & 5.144 & 62.629 & -57.485 \\
\hline 5 & 8.700 & 43.500 & -34.800 \\
\hline 6 & 12.199 & 79.851 & -67.652 \\
\hline 7 & 29.416 & 137.600 & -108.184 \\
\hline
\end{tabular}

Sesuai dengan Peraturan MNLH No. 1 Tahun 2010, maka syarat izin lingkungan yang berkaitan dengan pembuangan air limbah ke sungai Winongo mengikuti baku mutu air menurut PP No. 82 Tahun 2001. Oleh sebab itu, kegiatan-kegiatan yang merupakan sumber pencemar tertentu (point source) maupun sumber pencemar tak tentu (non-point source) di sepanjang sungai Winongo tidak boleh melebihi atau tidak sama dengan baku mutu air Kelas II, sebesar 3 $\mathrm{mg} / \mathrm{L}$ untuk BOD

\section{KESIMPULAN DAN SARAN}

\section{Kesimpulan}

1. Konsentrasi rata-rata $B O D$ disepanjang sungai Winongo yaitu sebesar $16 \mathrm{mg} / \mathrm{L}$, konsentrasi DO adalah $2,4 \mathrm{mg} / \mathrm{L}, \mathrm{pH}$ adalah 7 , suhu 26 oC
2. Konsentrasi BOD dari hulu ke hilir pada kondisi eksisting telah melebihi baku mutu air yang ditentukan yaitu sebesar $3 \mathrm{mg} / \mathrm{L}$

3. Beban pencemar Sungai Winongo dari hulu ke hilir telah melebihi daya tampung sungai terhadap beban pencemar yang ditunjukan daya tamping negatife. Upaya pengurangan beban pencemar disepanjang sungai Winongo dapat dilakukan dengan pembuatan IPAL komunal pada masing-masing kecamatan yang ada di sepanjang sungai Winongo

\section{Saran}

1. Perlu adanya data debit dan konsentrasi tentang limbah industri ataupun limbah rumah tangga yang masuk ke Sungai Winongo 
2. Perlu dilakukan identifikasi sumber pencemar baik point source maupun diffuse source yang masuk ke dalam sungai Winongo pada masing-masing segmen

3. Perlu dilakukan kegiatan evaluasi dan pemantauan air sungai secara rutin setiap bulan untuk mengetahui perubahan kualitas air yang lebih representative dan kaitannya dengan tingkat pemanfaatan air oleh masyarakat.

\section{UCAPAN TERIMA KASIH}

Terimakasih kepada semua pihak yang telah membantu atas terlaksananya penelitian tentang "Evaluasi Daya Tampung Beban Pencemar Menggunakan Model Kualitas Air “ khususnya kepada Pusat Studi Lingkungan Universitas Islam Indonesia

\section{DAFTAR PUSTAKA}

Agnes Dyah Novitasari Lestari.(20I2). Studi Pengaruh Hidrolika, Naungan, dan Point Source Terhadap Do-Bod Sungai Menggunakan Model Qual2Kw Studi Kasus :Sungai Gajah Wong. Tesis. Yogyakarta: Universitas Gadjah Mada.

Wulandari, Desy Aviliani .(2013). Analisis Daya Tampung Beban Pencemaran Kali Buduran, Kabupaten Sidoarjo dengan Metode QUAL2KW. Surabaya: ITS

Chapra, S.C, Pelletier, G.J. dan Tao, H. (2008). Qual2K A Modelling Framework for simulating River and Stream Water Quality; version 2.1I: Documentation and users Manual.USA: Tufts University, Medford.

Chapra S.C. (1997). Surface Water Quality Modeling. McGraw-Hill International Editions.

Nelly Marlina. (201I). Studi Daya Tampung Beban Pencemar Organik Biochemical Oxygen Demand (BOD) dengan Software Qual2K (Studi Kasus: Saluran Tarum Barat). Bandung: Teknik Lingkungan ITB

Peraturan Gubernur Daerah Istimewa Yogyakarta No. 22 tahun 2007 tentang Penetapan Kelas Air Sungai di Daerah Istimewa Yogyakarta 